I na koniec dodajmy, iż oprócz prawdy o przemianie Jerozolimy, ukazuje się również owo niezwykle istotne dążenie ludzi i pokoleń, marsz ku centrum świata, miejscu przebywania Boga. Lecz nie o wędrówkę do miejsca na ziemi tu idzie. Ta pielgrzymka obejmuje całe życie człowieka, który powołany jest do nieustannej metanoi, aby stać się w końcu godnym wejścia do Bram Jeruzalem Niebianskiego, by tam przebywać z Bogiem „twarzą w twarz” odtąd już na wieki.

Poznań

MAEGORZATA BEDYCHE

Ks. Jerzy Chmiel

\title{
PISMO ŚWIĘTE W DUSZPASTERSTWIE. KOMENTARZ DO DOKUMENTU „INTERPRETACJA BIBLII W KOŚCIELE"' (IV C 3)
}

Temat jak rzeka. Tyle już na ten temat napisano, że z lękiem przychodzi zbierać bibliografię. A jednocześnie jesteśmy jakby w punkcie wyjścia. Widocznie jest to temat, który ciągle wymaga nowego spojrzenia, choć wydaje się, że już wszystko powiedziano.

W niniejszym przedłożeniu ${ }^{1}$ pragnę oprzeć się na schemacie podanym … 'okumencie Papieskiej Komisji Biblijnej $O$ interpretacji Biblii w Kościele z 1993 r. (IV C 3), który traktując o posługiwaniu się Biblią w duszpasterstwie (dans le ministère pastoral) stanowi z kolei wykładnię soborowej konstytucji Dei Verbum (n. 24) ${ }^{2}$. Dokument (który w dalszym ciągu będzie przytaczany przy pomocy siglów: PKB) zwraca uwagę, że interpretacja zaleceń soborowych przybiera różne formy w zależności od rodzaju hermeneutyki stosowanego przez duszpasterzy.

${ }^{1}$ Komunikat wygloszony na 34 . sympozjum biblistów polskich w Radomiu w dniu 13. września $1996 \mathrm{r}$.

${ }^{2}$ Opieram się na oryginalnej wersji francuskiej L'interprétation de la Bible dans l'Eglise, Libreria Editrice Vaticana, Roma 1993. Por. również J. A. F i t z m y e r, The Biblical Commission's. Document „The Interpretation of the Bible in the Church". Text and Commentary (Subsidia biblica 18), PIB, Roma 1995. 
Możemy zapytać, jaki rodzaj hermeneutyki jest stosowany przez polskich duszpasterzy? Odpowiedź na to niełatwe pytanie spróbujemy dać przy omawianiu głównych działów pracy duszpasterskiej, jakimi są katecheza, kaznodziejstwo i apostolstwo biblijne.

\section{CZY KATECHEZA W POLSCE JEST UBIBLIJNIONA?}

Dokument PKB podkreśla pierwszorzędnym źródłem katechezy jest Pismo Święte tłumaczone w kontekście Tradycji. Jest to ważne stwierdzenie, gdyż często zapomina się, że "Tradycja i Pismo Święte stanowią jeden święty depozyt słowa Bożego powierzony Kościołowi” (DV 10). Celem katechizacji jest (a) wprowadzenie do właściwego zrozumienia Biblii, (b) owocna lektura i (c) jak najbardziej szczera odpowiedź na orędzie biblijne. Wielką pomocą jest Katechizm Kościola Katolickiego, który stara się realizować ten troisty cel. Wraca pytanie o rodzaj hermeneutyki stosowany przez katechetów.

$\mathrm{Na}$ pewno należy wyjść od kontekstu historycznego objawienia Bożego, a zatem od osób i wydarzeń Starego i Nowego Testamentu w świetle zamysłu Bożego. Dokument PKB zwraca uwagę na niebezpieczeństwo pozostawania na poziomie powierzchownego komentarza, polegającego na rozważaniu chronologicznego następstwa wydarzeń i postaci biblijnych. Chodzi więc o niebezpieczeństwo tzw. historycyzmu, zwanego inaczej biblicyzmem.

Ważną sprawą jest wykorzystywanie tekstów biblijnych w katechezie. Przeważnie wykorzystuje się najbardziej teksty narracyjne Starego i Nowego Testamentu. Tymczasem zostają w większej części nie wykorzystane teksty prorockie i mądrościowe, a z Nowego Testamentu mowy Jezusa, np. Kazanie na Górze.

Nie dysponując badaniami źródłowymi trudno jest teraz odpowiedzieć na pytanie, w jakim stopniu nowe publikacje katechetyczne uwzględniają postulaty katechizacji ubiblijnionej. Wydaje się jednak, że w polskiej katechezie przeważa typ hermeneutyki diachronicznej, którą można scharakteryzować poprzez pytania: „kto, kiedy, gdzie, ile?" Dokument PKB przypomina, że przedstawianie ewangelii powinno być spotkaniem z Chrystusem, który jest kluczem całego objawienia Bożego. Czy chrystocentryczna hermeneutyka ma zastosowanie we wszystkich programach katechetycznych, a co ważniejsze - w ogólnie stosowanej praktyce dydaktycznej, mogą pokazać tylko szczegółowe analizy, których brak jak dotąd.

Nieodzowna jest w katechezie aktualizacja przekazu biblijnego. "Słowo proroków i "sług Słowa" (Łk 1,2) winno być ukazane jako skierowane do chrześcijan aktualnie żyjących" (PKB). Potrzebna jest tu hermeneutyka krytyczna, to znaczy słowo Boże, skierowane do 
nas, interpeluje nas i osądza (biblijna krisis). Należałoby zapytać katechetów, czy spożytkowanie Pisma Świętego w jednostce katechizacyjnej prowadzi katechizowanych do dania osobistej odpowiedzi na orędzie Słowa. Można chyba mówić o braku hermeneutyki dialogicznej: w dydaktyce przeważa typ ekspozycyjny (wykład), rzadko spotyka się typ majeutyczny (dialog, dyskusja), prowadzący do wydobycia z ucznia osobistego odniesienia. Pokutuje jeszcze paradygmat „nauczyć się na pamięć” (czy lepsza pamięć, tym głębsza wiara), natomiast paradygmat świadectwa wiary zarezerwowany jest dla grup specjalnych - i to jeszcze od święta.

\section{KAZNODZIEJSTWO, CZYLI „SIEROCA CHOROBA” HOMILII}

Szokujący tytuł tego paragrafu chce wskazać na paradoksalną sytuację homilii, którą wszyscy chcą głosić, ale mało kto jest przekonany o jej użyteczności.

Kiedy bowiem mamy mówić o użytku Biblii w kaznodziejstwie, czyli w przepowiadaniu chrześcijańskim, nie sposób nie zacząć od homilii. Przede wszystkim nie każdy rodzaj kaznodziejstwa jest homilią, lecz tylko ten, który następuje w celebracji eucharystycznej po proklamacji Słowa Bożego, objaśniając je i wzywając do przyjęcia. Dalej, nie wolno mieszać homilii z egzegezą. Słuchacze są częstokroć przytłoczeni wiedzą kaznodziei, który próbuje im wtłoczyć do głowy rozmaite schematy i paradygmaty, obce słowa i multum tekstów.

Dokument PKB przestrzega przed tego rodzaju nagromadzeniem idei, które z punktu widzenia retoryki są tylko balastem. Stąd nieraz słychać odgłosy ulgi po skończeniu mistrzowsko przygotowanej wysokiej egzegezy dla maluczkich... Homilia powinna nie tylko pouczyć, ale i pociągnąć: „non solum docere, sed etiam trahere” - to jedna z zasad klasycznej retoryki. Dlatego potrzebna jest w homilii aktualizacja i inkulturacja. Jak utrzymuje Joseph A. Fitzmyer SI, inkulturacja jest specyficzną formą aktualizacji ${ }^{3}$. Stąd potrzeba znajomości reguł hermeneutycznych, ażeby nie spłaszczyć w przesadnej modernizacji (inne określenie aktualizacji) Słowa Bożego. Przestrzega przed tym dokument PKB: brak odpowiedniego przygotowania, ze strony homilety może prowadzić albo do moralizowania, albo do socjologizowania, gdzie traci się smak i wartość orędzia biblijnego ${ }^{4}$.

${ }^{3}$ Dz. cyt., s. 176.

${ }^{4}$ Polskiemu piśmiennictwu przyswojono ostatnio pracę $\mathrm{R}$. Z e rf a s s a Od perykopy do homilii, Kraków 1995. 
Dokument PKB postuluje udział egzegetów w tworzeniu odpowiednich pomocy homiletycznych. Takich pomocy nie brakuje w Polsce, bieda chyba w tym, że kaznodzieje częstokroć preferują gotowe wzorce do wygłoszenia (resp. odczytania) niż materiały, refleksje i pomoce pogłębiające tematykę.

Papieska Komisja Biblijna jakby proponowała biblijny model przepowiadania na przykładzie perykopy J 4, cytując zwrot z J 4,10: „poznać dar Boży” użyty przez Jezusa w rozmowie z Samarytanką. Poddajmy krótkiej analizie semiotycznej tę perykopę $\mathrm{w}$ odniesieniu do naszego tematu.

(1) Jezus spotyka Samarytankę jak gdyby przypadkowo. Przypadek ten był regulowany potrzebą zaczerpnięcia wody ze studni i odpoczynku przy niej.

(2) Zaczyna się rozmowa na temat sposobu czerpania wody: a więc od czegoś bardzo konkretnego.

(3) Rozmowa przechodzi na temat „daru wody żywej”.

(4) Jezus odwołuje się do sytuacji życiowej kobiety (aktualizacja).

(5) Następuje wywód na temat czci Ojca w Duchu i prawdzie.

(6) Wyznanie Jezusa, że jest Mesjaszem.

(7) Przybycie świadków, którzy uwierzyli kobiecie.

(8) Uwierzenie w Jezusa, który wśród nich krótko przebywał.

\section{APOSTOLSTWO BIBLIJNE JAKO POZNANIE DARU BOŻEGO}

Do zadań apostolstwa biblijnego dokument PKB zalicza:

- tworzenie nowych przekładów biblijnych i rozpowszechnianie ich;

- inspirowanie inicjatyw, formacja grup biblijnych, tygodnie biblijne, konferencje, publikacja czasopism i książek itd.

Wielki wklad mają tutaj stowarzyszenia i ruchy kościelne, które stawiają na pierwszym miejscu lekturę Biblii w perspektywie wiary i chrześcijańskiego zaangażowania. Zwykło się je nazywać „communautés de base” (polska propozycja nazewnictwa: „wspólnoty podstawowe", Cclem ich jest: (a) poznanie Biblii, (b) tworzenie wspólnoty i (c) służba społeczeństwu. Warto zwrócić uwage, że wśród wielu ruchów „importowanych” do Polski z zagranicy jest jeden ruch, który powstał na gruncie rodzimym, mianowicie Ruch Światło-Zycie, założony przez ks. Franciszka Blachnickiego, Sługę Bożego. Ruch ten, związany z posługą ministrantów i służby liturgicznej ołtarza,

${ }^{5}$ Perykopa ta była leitmotiwem obrad V Zgromadzenia Ogólnego Katolickiej Federacji Biblijnej w Hongkongu, w dniach 2-12 lipca 1996, którego hasło brzmiało „Słowo Boże źródłem życia”. 
eksponuje bardzo wyraźnie lekturę i studium Pisma Świętego na różnych swych stopniach ${ }^{6}$.

Dokument PKB zwraca uwage na dwa ważne momenty w formowaniu się takich wspólnot. Pierwszym momentem jest pomoc egzegetów dla uniknięcia dewiacji w aktualizacji przesłania biblijnego. Bibliści nie powinni więc odmawiać fachowej pomocy tym grupom. Ażeby jednak naukowa egzegeza nie zawłaszczyła bez reszty tych ruchów, a w pewien sposób ich nie zniszczyła, drugim momentem jest udział ludzi prostych, którzy potrafią do interpretacji i aktualizacji Biblii dodać swoje własne doświadczenie i treści duchowe. Jeden z tłumaczy angielskich miał zwyczaj czytać dokerom w porcie swoje biblijne przekłady. Jeśli nie były dla nich zrozumiałe, targał tekst i zabierał się do nowego przekładu.

O roli tych ludzi prostych w recepcji Bożego objawienia jest mowa w Mt 11,25, kiedy Jezus mówił: „Wysławiam Cię, Ojcze, Panie nieba i ziemi, że zakryłeś te rzeczy przed mądrymi i roztropnymi, a objawiłeś je ludziom prostym". Owi mądrzy i roztropni (sofoí, synetoí) to fachowcy, egzegeci, teologowie, ich przeciwstawieniem albo raczej uzupełnieniem - są neppioi, co dosłownie znaczy: „niemowlęta”, a chodzi o ludzi niewykształconych (w polskich przekładach: „prostaczek”7). Moglibyśmy tutaj powiedzieć o dwóch płucach hermeneutycznych: płuco wiedzy i nauki przechodzącej nieraz - niestety - w pychę oraz płuco otwarcia i wrażliwości przechodzącej w pokorę.

Nie można nie doceniać roli i znaczenia środków społecznego przekazu (mass-media): prasa, radio i telewizja. Pismo Święte powinno być $\mathrm{w}$ tych środkach aktywnie propagowane $\mathrm{z}$ zachowaniem jak przypomina dokument PKB - należytego umiaru, szacunku i proporcji wobec misterium Bożego objawienia. Chodzi tutaj zarówno o wyeliminowanie wszelkiej manipulacji słowem Bożym, jak również o stosowanie odpowiednich metod komunikacji, które można by określić terminami: decus-dignitas-discretio.

Gdy mówimy o apostolstwie biblijnym, nie możemy pominąć milczeniem tej organizacyjnej formy, jaką jest od ponad 25 lat Katolicka Federacja Biblijna ${ }^{8}$.

${ }^{6}$ Ruch Światło-Życie obchodził w r. 1996 w archidiecezji krakowskiej 25-lecie swojego istnienia. Uroczystości jubileuszowe miały miejsce w Kalwarii Zebrzydowskiej w dniu 31 sierpnia $1996 \mathrm{r}$.

${ }^{7}$ Anna Świderkówna w swoim najnowszym tłumaczeniu Ewangelii św. Mateusza (Kraków 1995) słusznie tłumaczy przez „małe dzieci”, tzn. ludzie, którzy nie umieją jeszcze nawet mówić, lecz mogą i chcą się uczyć.

${ }^{8}$ Zob. J. C h m i e 1, 25-lecie Katolickiej Federacji Biblijnej, „Ruch Bibl. i Lit." 47/1994/284-85; S. H a r e z g a, Światowe inicjatywy apostolatu biblijnego w „Bulletin Dei Verbum” Katolickiej Federacji Biblijnej", tamże, 256-62. 
W lipcu 1996 r. w Hongkongu miało miejsce V Walne Zgromadzenie tejże Federacji. Uchwalona tamże rezolucja końcowa zawiera szereg propozycji, z których wiele warto by od zaraz realizować.

(1) Troszczyć się o poznanie zdrowych zasad egzegezy i hermeneutyki biblijnej. W tym celu zaleca się studium dokumentu PKB.

(2) Promować w studium akademickim kurs o czytaniu Biblii w Kościele w aspekcie historycznym, hermeneutycznym i pastoralnym.

(3) Starać się o zachowanie proporcji między egzegezą naukową a doświadczeniem pastoralnym w różnego rodzaju akcjach i spotkaniach.

(4) Poszukiwać nowych efektywnych form w propagowaniu Biblii, zwłaszcza wśród młodych, biednych, żyjących na marginesie, ażeby połączyć elementy orędzia biblijnego, życia, liturgii i katechezy.

(5) Wspólnotowe czytanie Biblii winno być dialogiczne na wszystkich płaszczyznach: dialog między nauczającymi a uczącymi się, dialog z innymi religiami i kulturami, ze szczególną troską o kultury słabsze i miejscowe.

(6) Taki dialog wokół i dla Biblii winien wyzwolić ducha prawdziwej solidarności, która polega nie tylko na wymianie słów i idei, lecz jest uczestnictwem w życiu bliźniego.

\section{W POSZUKIWANIU ADEKWATNEGO MODELU WSPÓŁDZIAEANIA MIĘDZY BIBLISTYKA A DUSZPASTERSTWEM}

Wraca na końcu pytanie postawione na początku naszych rozważań: jaki rodzaj hermeneutyki jest najlepszy dla duszpasterzy albo jaki preferować model współpracy między egzegetami a duszpasterzami?

O ile relacja biblistyki do Urzędu Nauczycielskiego została określona (DV 12: badanie przygotowawcze, aby sąd Kościoła nabywał dojrzałości), o tyle relacja biblistyki do duszpasterstwa wydaje się być często wypadkową spontaniczności i podejrzliwości. Egzegeci wysuwają pretensje pod adresem duszpasterzy, że nie realizują ich badań, podczas gdy duszpasterze mają żal do egzegetów, że zbyt często zostali wpuszczeni w maliny.

Wydaje się, że relacja ta winna polegać na zaufaniu i współpracy obydwu stron w ciągłym nadsłuchiwaniu, co Duch mówi Kościołowi. Można zaproponować model, znany z socjologii i pedagogiki, który nosi nazwę: „samospełniające się proroctwo" (self-fulfilling 
prophecy) $)^{9}$. Model ten ma miejsce, kiedy oczekiwania i przewidywania nauczyciela dotyczące zachowania ucznia i jego postępów w nauce są przyczyną kształtującą zachowania i postępy stosownie do tego, czego spodziewał się nauczyciel. W modelu tym oczekiwania biblistów i duszpasterzy wywołują pewien cykl, jak to przedstawia rysunek.

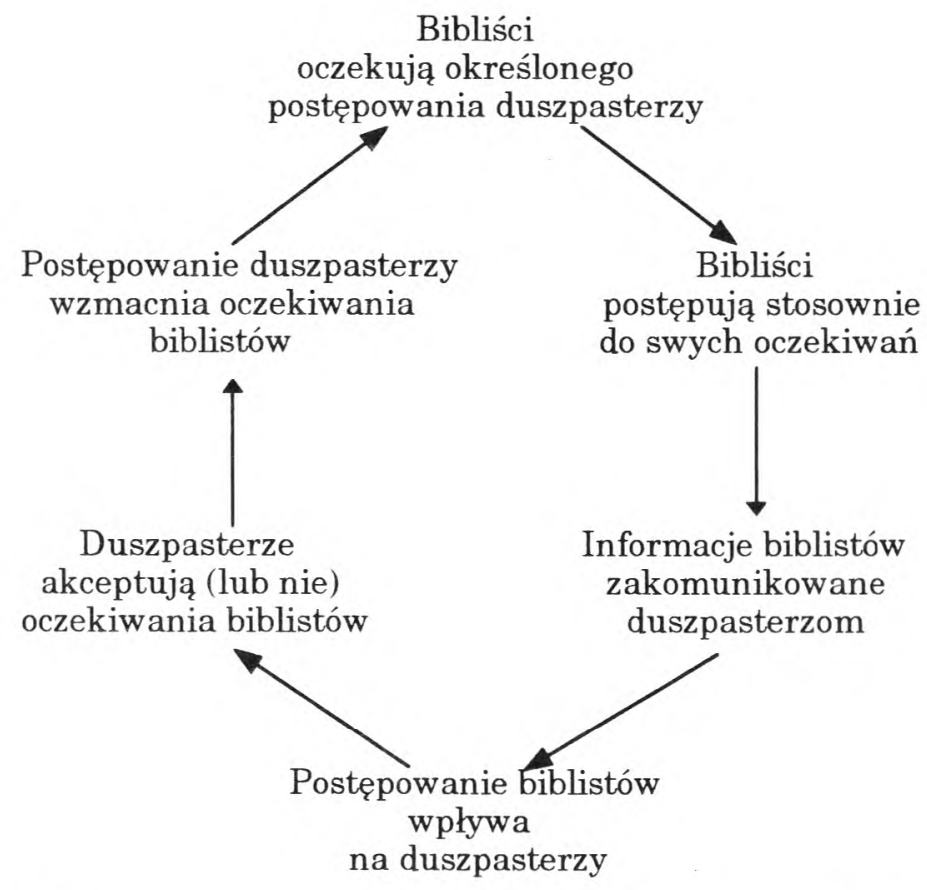

Kraków

Ks. JERZY CHMIEL

${ }^{9}$ Por. R. M e r t o n, Teoria socjologiczna $i$ struktura spoleczna, PWN, Warszawa 1968; R. I. A $\mathrm{r}$ e n d s, Uczymy się nauczać, WSiP, Warszawa 1995. Niewątpliwy wpływ na powstanie tego modelu socjopedagogicznego miał mechanizm biblijnych proroctw. Możemy tu mówić o jakiejś Wirkungsgeschichte. 